\title{
AMCoR
}

Asahikawa Medical College Repository http://amcor.asahikawa-med.ac.jp/

Transactions of the Royal Society of Tropical Medicine and Hygiene (2009) 103(3):255-261.

Paragonimiasis in Cameroon: molecular identification, serodiagnosis and clinical manifestations

Nkouawa, Agathe ; Okamoto, Munehiro ; Mabou, Alida Kouojip ; Edinga, Eulodie ; Yamasaki, Hiroshi ; Sako, Yasuhito ; Nakao, Minoru ; Nakaya, Kazuhiro ; Blair, David ; Agatsuma, Takeshi ; Enyong, Peter ; Shibahara, Toshiyuki ; Moyou-Somo, Roger ; Ito, Akira 
Manuscript number: TRSTMH-D-07-00209

\section{Paragonimiasis in Cameroon: Molecular Identification, Serodiagnosis and Clinical Manifestations}

Agathe Nkouawa ${ }^{\mathrm{a}, \mathrm{b}, 1}$, Munehiro Okamoto ${ }^{\mathrm{c}, 1}$, Alida Kouojip Mabou ${ }^{\mathrm{d}}$, Eulodie Edinga ${ }^{\mathrm{e}}$, Hiroshi Yamasaki ${ }^{\mathrm{a}}$, Yasuhito Sako ${ }^{\mathrm{a}}$, Minoru Nakao ${ }^{\mathrm{a}}$, Kazuhiro Nakaya ${ }^{\mathrm{f}}$, David Blair ${ }^{\mathrm{g}, 1}$, Takeshi Agatsuma $^{\mathrm{h}}$, Peter Enyong ${ }^{\mathrm{b}}$, Toshiyuki Shibahara ${ }^{\mathrm{i}}$, Roger Moyou-Somo $^{\mathrm{b}, \mathrm{e}}$ and Akira Ito $^{\mathrm{a},{ }^{*}, 1}$

${ }^{1}$ These authors worked equally.

* Corresponding author: Prof. Akira Ito, Department of Parasitology, Asahikawa Medical College, Midorigaoka Higashi 2-1-1-1, Asahikawa, Japan. Tel.: +81 16668 2421; fax: +81 166682429. E-mail address: akiraito@asahikawa-med.ac.jp

${ }^{a}$ Department of Parasitology Asahikawa Medical College, Asahikawa, Japan

${ }^{b}$ Medical Research Center, Institute of Medical Research and Study of Medicinal Plants (IMPM), Yaounde, Cameroon

c Department of Laboratory Animal Science, School of Veterinary Medicine, Faculty of Agriculture, Tottori University, Tottori, Japan

${ }^{\mathrm{d}}$ District Hospital of Palm City, Ministry of Health, Douala, Cameroon

e Department of Parasitology and Infectious Diseases, Faculty of Medicine and Biomedical Sciences, University of Yaounde I, Yaounde, Cameroon

${ }^{\mathrm{f}}$ Animal Laboratory for Medical Research, Asahikawa Medical College, Asahikawa, Japan; 
${ }^{g}$ School of Marine and Tropical Biology, James Cook University, Townsville, Queensland, Australia

${ }^{\mathrm{h}}$ Department of Environmental Health Science, Faculty of Medicine, Kochi University, Kochi, Japan

${ }^{\mathrm{i}}$ Division of Laboratory Animal Science, Research Center for Bioscience and Technology, Tottori University, Tottori, Japan

\section{Summary}

Paragonimiasis is a common parasitic zoonosis in Cameroon and neighboring countries in Western Africa. Serum, sputum and faecal samples were collected in an endemic area of South West Province, Cameroon, after administration of a questionnaire to identify individuals with appropriate symptoms and histories. Microscopic examination revealed eggs in sputum from 16 people, but none in any faecal sample. These 16 were among the 25 and 26 people respectively positive by enzyme-linked immunosorbent assay (ELISA) and by immunoblot using Paragonimus africanus crude antigens. The detection of copro-DNA by polymerase chain reaction (PCR) was attempted using 23 faecal samples (18 from sputum egg-negative and 5 from sputum egg-positive individuals). The copro-DNA was detected in 4 of the 5 sputum eggpositive individuals. These results suggest that (1) serology is much more sensitive than sputum examination for diagnosis of paragonimiasis, and (2) a copro-DNA test may be more sensitive than a microscopic search for eggs in faeces. Molecular sequence data from ITS2 and cox1 genes confirmed that adult worms experimentally raised in cats were P. africanus and that eggs from sputum or other worm products from human faeces also belonged to this species. Based on these results, 26 of 168 persons (15.5\%) were diagnosed as suffering from paragonimiasis.

Keywords: Paragonimus africanus; Paragonimiasis; Serology; Copro-DNA; Cameroon. 


\section{Introduction}

Paragonimiasis is a parasitic disease of humans and other mammals caused by infection with adult Paragonimus spp. (lung flukes). It has been estimated that 21 million people are currently infected in Southeast Asia, South America and Africa (WHO, 1995) and 290 million people are at risk of paragonimiasis (Keiser and Utzinger, 2005). The disease is endemic in Africa particularly in the West and Central Equatorial region (WHO, 1995; Boguikouma et al., 1997; Arene et al., 1998). In this area, paragonimiasis and tuberculosis co-exist. The prevalence of the latter, following the spread of HIV infection, is high in Cameroon with $>300$ cases per 100,000 inhabitants (WHO, 2002). As the symptoms of paragonimiasis and tuberculosis are similar, potentially leading to diagnostic confusion, it is important to differentiate between them (WHO, 1995).

In Cameroon, epidemiological and clinical studies on paragonimiasis based on parasitological investigations and the discovery of eggs in sputa have reported prevalences from 3.0 to $9.6 \%$ (Ripert et al., 1992; Ollivier et al., 1995; Moyou and Tagni-Zukam, 2003; Moyou et al., 2003). However, it is very difficult to detect eggs during the pre-patent period, in singleworm infections, or in cases of extra-pulmonary paragonimiasis (including cerebral paragonimiasis). Furthermore, eggs are not found in every sputum sample, even in typical pulmonary paragonimiasis (Yokogawa, 1965; Blair et al., 2007). Therefore, any epidemiological survey based only on egg detection will underestimate the true prevalence.

Enzyme-linked immunosorbent assay (ELISA) and immunoblot have been used for serodiagnosis of paragonimiasis in Asia and Latin America (Ikeda et al., 1996; Kong et al., 1998; reviewed by Blair et al., 2007). In Africa, however, there have been no studies on paragonimiasis based on immunological or molecular tools. 
This study was conducted to identify the Paragonimus species present in an endemic area in Cameroon, to compare the sensitivities of serodiagnostic and microscopic methods in diagnosis and to evaluate a copro-DNA test for the detection of parasite DNA from faeces.

\section{Materials and Methods}

\subsection{Study sites}

Four villages, Bulutu, Ebonji, Etam and Teke, were selected for this study. They are located in the Tombel Health District (50,000-100,000 inhabitants) in the rain forest zone about $40 \mathrm{~km}$ northwest of Kumba, Manengouba Department, South West Province of Cameroon (4² $3^{\prime}$, $\left.9^{\circ} 3^{\prime} \mathrm{W}\right)$. The annual average temperature is $24^{\circ} \mathrm{C}$ and the relative humidity varies from $52 \%$ to 74\%. Agriculture is the principal economic activity; hunting and fishing are also practiced. The study area is known to be the most endemic for paragonimiasis in Cameroon because the population of this area habitually eats crabs.

\subsection{Parasite materials and preparation of Paragonimus antigens}

Two cats were each experimentally infected with 40 Paragonimus metacercariae obtained from crabs (Sudanonautes africanus) collected at Bulutu. Ethics approval was granted by the National Ethics Committee of Cameroon, Yaounde, Cameroon. Two months after inoculation, flukes were recovered from the lungs of the cats under humane conditions and used for further investigations. The frozen adult worms $(0.5 \mathrm{~g})$ were ground in $200 \mu$ l phosphate-buffered saline (PBS, $\mathrm{pH} 7.2)$ with a Teflon-homogenizer and centrifuged at $20,000 \mathrm{~g}$ for $10 \mathrm{~min}$ at $4{ }^{\circ} \mathrm{C}$. The supernatants were used as crude antigens and stored at $-20^{\circ} \mathrm{C}$. The concentration of the antigen was estimated by using the Bicinchoninic acid (BCA) protein assay kit (Pierce Biotechnology Inc., Rockford, IL, USA). 


\subsection{Human samples}

The survey, approved by the National Ethics Committee of Cameroon, was conducted in the general population in January 2004 and February 2006. The chief of each village was informed about the study and participants or parents/guardians gave informed consent for participation. People living in the area were asked whether they had experienced symptoms such as cough, haemoptysis, headache, epilepsy and chest pain, and whether they consumed raw and/or undercooked crabs. Following this, serum, sputum and faecal samples were collected from 168 people, all of who habitually ate crabs $(28,52,55$ and 33 from Bulutu, Ebonji, Etam and Teke villages, respectively). Sputum samples and faeces were examined in Cameroon for the presence of eggs to provide a diagnosis of paragonimiasis. Stool examination was performed using the formalin-ether concentration method (Ritchie, 1948). Serum samples, a small number of faecal samples $(n=23)$ and the parasite specimens were examined in Japan. Serum samples from healthy donors from areas endemic (10 samples) and non-endemic ( 9 samples) for paragonimiasis were also collected. All individuals found to have eggs in the sputum were treated with praziquantel at a dose of $3 \times 25 \mathrm{mg} / \mathrm{kg}$ of body weight per day for 3 consecutive days. Serum samples from confirmed cases infected with $P$. westermani $(\mathrm{n}=57)$ and $P$. miyazakii $(\mathrm{n}=7)$ in Japan were also used.

For evaluation of the specificity of $P$. africanus antigens, 68 serum samples from patients with other helminthic infections were used (Xiao et al., 2003). These included the cases of schistosomiasis haematobium $(n=10)$, schistosomiasis japonicum $(n=10)$, fascioliasis $(n=10)$, clonorchiasis $(n=19)$, cysticercosis $(n=10)$ and sparganosis $(n=9)$.

\subsection{Morphological observation of the lung flukes}


Adult lung flukes recovered from experimentally infected cats were originally preserved in RNAlater (Qiagen, Hilden, Germany) for RNA preparation. Some were later stained with acetocarmine for morphological observation.

\subsection{Molecular identification and phylogenetic analysis of the lung flukes}

DNA was extracted from adult worms using a QIAamp DNA Mini Kit (Qiagen, Hilden, Germany). The internal transcribed spacer 2 region (ITS2) of ribosomal DNA was amplified by polymerase chain reaction (PCR) using a forward primer 5'-CGGTGGATCACTCGGCTCGT-3' (3S) and a reverse primer 5'-CCTGGTTAGTTTCTTTTCCTCCGC-3' (A28) (Bowles et al, 1995; Blair et al., 1997). A portion of the mitochondrial cytochrome $c$ oxidase subunit 1 gene (cox1) was also amplified using a forward primer 5'-TGGTTTTTTGTGCATCCTGAGGTTTA-3' (pr-a) and a reverse primer 5'-AGAAAGAACGTAATGAAAATGAGCAAC-3' (pr-b) (Okamoto et al., 1995). DNA sequencing was carried out using an ABI PRISM BigDye Terminator v 3.1 Cycle Sequencing Ready Reaction Kit and an ABI PRISM 310 Genetic Analyzer (Applied Biosystems, Foster City, CA, USA).

DNA sequence data were aligned using the CLUSTAL W computer program (Thompson et al., 1994). Pairwise evolutionary distances were computed by Kimura's two-parameter method (Kimura, 1980) and the phylogenetic tree was constructed by the neighbor-joining method (Saitou and Nei, 1987) implemented in MEGA version 3.1 (Kumar et al., 2004).

\subsection{Detection of Paragonimus DNA in faeces of paragonimiasis patients}

DNA was extracted from 23 human faecal samples using a QIAamp DNA Stool Mini Kit (Qiagen, Hilden, Germany): 5 (code ET56, T76, T86, T92, E20 in Table 1) were from individuals who were both sputum egg-positive and sero-positive and 18 were from egg-negative individuals. 
Among the egg-negative samples, 2 (B07, B08 in Table 1) and 16 (not included in Table 1) were sero-positive and sero-negative, respectively. PCR-amplification and DNA sequencing of ITS2 and cox1 genes was performed according to the above-mentioned methods.

\subsection{Serodiagnosis}

Crude adult antigens from $P$. africanus, $P$. westermani and $P$. miyazakii were used for both ELISA and immunoblots. ELISA was performed on 168 samples as reported in previous studies on paragonimiasis (Ikeda et al., 1996; Kong et al., 1998) with slight modifications. Briefly, 96well microtiter plates (Maxisorp; Nunc, Roskilde, Denmark) were coated with each of the crude antigens at a concentration of $5 \mu \mathrm{g} / \mathrm{ml}$ of protein in phosphate buffer saline (PBS) and incubated at $4^{\circ} \mathrm{C}$ overnight. The microtiter plates were probed with 1:200-diluted human serum samples in blocking buffer. Peroxidase-conjugated rec-Protein G (Zymed, San Francisco, USA) diluted in 1:4,000 was added into each well. Peroxidase activity was revealed by adding $0.4 \mathrm{mM} 2,2$-azino-

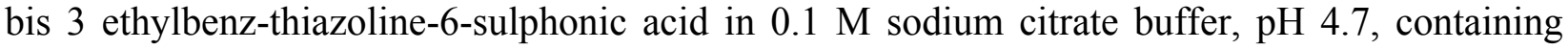
$0.003 \% \mathrm{H}_{2} \mathrm{O}_{2}$ at room temperature (RT). The optical density (OD) was monitored at $405 \mathrm{~nm}$ on a microplate reader (ImmunoMini, model NJ-2300; Nalgene Nunc International, Tokyo Japan). The cut-off value was calculated for each antigen based on the means of pooled serum samples from healthy donors.

An immunoblot assay was performed (on 64 samples including all samples positive or borderline by ELISA and samples lying just below the ELISA cut-off value) as described previously (Ito et al., 1998; Kong et al., 1998) with modifications. The antigens $(80 \mu \mathrm{g} / \mathrm{mini}$ slab gel) from P. africanus, $P$. westermani and P. miyazakii were separated on $15 \%$ polyacrylamide gels containing $0.4 \%$ SDS and electrotransferred onto an Immobilon-P transfer membrane (pore size $0.45 \mu \mathrm{m}$, Millipore, Tokyo, Japan) overnight. The membrane was cut into strips and probed 
with 1:50-diluted human serum in blocking buffer at RT for $1 \mathrm{~h}$. The strips were incubated for $1 \mathrm{~h}$ in 1:1000-diluted peroxidase-conjugated rec-Protein G. The substrate, 4-chloro-1-naphtol (Nacalai Tesque, Tokyo, Japan) was added for color development. The reaction was stopped with excess distilled water.

In order to evaluate the specificity of $P$. africanus antigens, ELISA and immunoblot were performed using serum samples from patients with other helminthic infections described above (Xiao et al., 2003).

\section{Results}

\subsection{Morphological and molecular identification of the Paragonimus species used for antigen preparation.}

The morphology of immature and mature lung flukes obtained from experimentally infected cats was observed using aceto-carmine stained specimens. It was difficult to confirm critical morphological differences between $P$. africanus and other species due to poor initial preservation of the specimens in RNAlater. However, 5 uterine eggs from 5 adult worms averaged about 90 $\mu \mathrm{m}$ in length (data not shown), a size typical of $P$. africanus.

Unambiguous sequences of $445 \mathrm{bp}$ spanning the ITS2 region were obtained from three adult worms. Two individuals had identical sequences (DDBJ/EMBL/GenBank accession no. AB298779) that differed at two nucleotide positions from the third sequence (accession no. AB298780). The last was identical with the ITS2 region from P. africanus (Blair et al., unpublished data). The phylogenetic tree of Paragonimus spp. (including Euparagonimus), inferred from ITS2 sequences showed that our newly acquired sequences clustered unambiguously with $P$. africanus (data not shown). Unambiguous sequences of $391 \mathrm{bp}$ of the cox1 gene were also obtained from adult worms. Again, two individuals had identical sequences 
but the third was slightly different (99.3\% similarity). All differences in the cox 1 sequences were synonymous substitutions, supporting the view that all came from the same species.

\subsection{Molecular diagnosis}

Figure 1 showed the results of copro-DNA test. Of 23 faecal samples examined, the ITS2 region and partial cox1 gene could be amplified from 4 samples from sero-positive individuals with eggs in their sputum (lanes 3, 5, 6, and 7 in Figure 1). The ITS2 and cox1 sequences of all the four were identical with those of $P$. africanus (data not shown). The faecal sample of one serologically positive individual with eggs in the sputum failed to yield amplifiable copro-DNA (lane 4 in Figure 1 and code ET56 in Table 1).

\subsection{Serological, parasitological and clinical evaluation}

The results of ELISA using P. africanus antigens were illustrated in Figure 2. Of 168 serum samples examined, $25(14.8 \%)$ were sero-positive and additional 4 samples were regarded as borderline. Figure 3 showed immunoblot patterns of $P$. africanus, $P$. westermani and $P$. miyazakii antigens with serum samples from confirmed single-infection cases. All the sera crossreacted with the antigens of the three species, although the serum of $P$. miyazakii cases appeared to be relatively weakly immunoreactive. The antigens from Japanese $P$. westermani and $P$. miyazakii provided similar results in ELISA and immunoblot with the Cameroon serum samples. Similarly, serum samples from confirmed P. westermani and P. miyazakii cases in Japan showed very similar results in both ELISA and immunoblot using crude antigens of $P$. africanus (data not shown). The antigens from the three species showed basically similar banding patterns with particularly pronounced bands having molecular weights of approximately 35, 33, 27 and 16-18 kDa (Figure 3). The immunoblot assay using P. africanus antigens was carried out to confirm the 
results of ELISA (Figure 2 and Supplementary figure). Of 64 samples including 25 positives, 4 borderlines and 34 negatives by ELISA, 18 samples strongly reacted with both the 33 and $35 \mathrm{kDa}$ components and 8 samples giving a weak response only to other components. Seventeen of the 18 strongly positive samples had OD values higher than 0.4 in the ELISA test. Seven samples weakly positive by ELISA (open circles in Figure 2) and one sample just below the ELISA cutoff value (an open square in Figure 2) were weakly positive by immunoblot, reacting only with the 16-18 $\mathrm{kDa}$ bands. Four borderline samples by ELISA showed negative results in the immunoblot. The specificity of $P$. africanus antigens was evaluated by ELISA and immunoblot with serum samples from patients with other helminth infections. Sera from a patient with sparganosis and a patient with fascioliasis cross-reacted weakly with $P$. africanus antigens by ELISA, but not by immunoblot (data not shown).

The parasitological, clinical and serological data of the people diagnosed as suffering from paragonimiasis were summarized in Table 1. The people enrolled in this study (78 males and 90 females) suffered from cough (80.3\%), haemoptysis (11.3\%), chest pain (47.6\%), epilepsy $(8.3 \%)$ and headache $(63.0 \%)$. They ranged in age from 4 to 78 years $(15.2 \pm 8.2$ years in males and $12.9 \pm 5.9$ years in females). All the immunoblot-positive patients had histories of eating raw or undercooked crabs and were suffering from cough (Table 1). No Paragonimus eggs were detected microscopically in any faecal samples using the formalin-ether concentration method. According to these results, $26(15.5 \%)$ persons were diagnosed as positive for paragonimiasis.

Paragonimiasis cases were confirmed from all four villages. Seroprevalence differed greatly among the four villages: $25.0 \%$ (7/28, Bulutu), 7.6\% (4/52, Ebonji), 16.3\% (9/55, Etam) and $18.1 \%(6 / 33$, Teke). 


\section{Discussion}

We reported the results of a survey for paragonimiasis in South West Province, Cameroon, and the identity of the causative species based on molecular sequences. Of 168 persons with appropriate symptoms and a history of eating raw or undercooked crabs, $26(15.5 \%)$ were seropositive for paragonimiasis, all but one both by ELISA and immunoblot. Among these seropositive individuals, 16 were found to have eggs in their sputum. Four (of five tested) of these were positive for copro-DNA by using PCR. It is known that P. africanus, P. uterobilateralis $P$. westermani-like and Euparagonimus sp. occur in Cameroon (Voelker and Sachs, 1977; Cabaret et al., 1999). However, P. africanus is the only species confirmed from humans in Cameroon so far (Moyou et al., 2003) and our molecular analyses are in agreement with that.

Serology had much higher sensitivity for diagnosis of African paragonimiasis (26 positive) than did examination of sputum for eggs (16 positive). This is in agreement with findings from other parts of the world (Toscano et al., 1995; Kong et al., 1998). Examination of faeces for eggs is the least sensitive method (Yokogawa, 1965). Our examination failed to detect eggs in any of the faecal samples, although the copro-DNA approach did detect DNA from eggs or other products of lungworms in four of five individuals with eggs in their sputum. Failure in this one case could be because some people do not swallow sputum. Similar methods to detect copro-DNA have been developed for schistosomiasis (Gobert et al., 2005) and cestode infections (Yamasaki et al., 2004; Mathis and Deplazes, 2006). Intapan and others (2005) have demonstrated that the approach is effective in diagnosing $P$. heterotremus in cats. We speculate that PCR using DNA from sputum might prove to be an ideal tool for detection of pulmonary paragonimiasis cases, since sputum might contain products of developing lung flukes that might allow detection of pre-patent cases. 
The antigens of three Paragonimus species reacted with serum samples from Cameroon and from Japan, exhibiting very similar sensitivity and specificity by ELISA and immunoblot. The three species showed similar immunoblot patterns with four major bands. Among them, both 33 and $35 \mathrm{kDa}$ bands were recognized most strongly by sera showing OD values higher than 0.4 by ELISA. Similar 33 and $35 \mathrm{kDa}$ proteins in crude antigens of $P$. westermani adults were shown to elicit the most specific and strongest reactions with IgG4 of paragonimiasis patients from the early stage to chronic infection (Kong et al., 1998). Clearly, it is difficult to differentiate the Paragonimus species by immunoblot. The immunodominant antigens with utility for serodiagnosis of paragonimiasis appear to be genus specific (Kong et al., 1998).

To our knowledge, this is the first report confirming paragonimiasis in humans using a copro-DNA test. This approach should be evaluated further using more faecal samples and highly specific and sensitive primers (Intapan et al., 2005). Serology, the copro-DNA test and detection of eggs in sputum (or faeces) are essential for differentiation of paragonimiasis from other diseases. Of the 168 symptomatic people we evaluated, 26 were confirmed as paragonimiasis cases. The sero-negative persons should be followed-up to exclude tuberculosis or other diseases. A previous study conducted in the same area failed to find any tuberculosis cases among those enrolled (Moyou et al., 2003). Individual No. 72 in Table 1 is interesting, since he was sero-positive but eggs were not found in his sputum. His reported history of epilepsy might indicate a case of cerebral rather than pulmonary paragonimiasis. Further studies using modern tools are necessary to understand the epidemiology of paragonimiasis in Cameroon and other African countries. 
Authors' contributions: RMS and AI conceptualized and designed the study; AN, MO, HY and MN carried out mitochondrial analysis; AKM, EE, PE and RMS carried out epidemiological studies, collection of the specimens and experimental infections in Cameroon; AN, YS, AI carried out serology; MO, KN, TS carried out morphological analysis; AN, MO, DB and TA carried out molecular phylogenetic analysis; AN, MO, DB, AI drafted the manuscript. All authors read and approved final manuscript. Both RMS and AI are guarantors of the paper.

Funding: The Leadership in Science and Technology in Asia from Ministry of Education, Culture, Sports, Science and Technology, Japan, International Collaboration Research Fund from the Japan Society for the Promotion of Science (JSPS) (14256001, 17256002) and JSPSAsia/Africa Science Platform Fund to A. I.

Conflicts of interest: None declared

Ethical approval: The National Ethics Committee of Cameroon, Yaounde, Cameroon

Appendix A. Supplementary figure

Supplementary figure associated with this article can be found, in the online version, at....

\section{References}

Arene, F., Ibanga, E., Asor, J.E., 1998. Epidemiology of paragonimiasis in Cross River basin, Nigeria: prevalence and intensity of infection due to Paragonimus uterobilateralis in Yakurr local government area. Public Health 112, 119-122. 
Blair, D., Van Herwerden, L., Hirai, H., Taguchi, T., Habe, S., Hirata, M., Lai, K., Upatham, S., Agatsuma, T., 1997. Relationships between Schistosoma malayensis and other Asian schistosomes deduced from DNA sequences. Mol. Biochem. Parasitol. 85, 259-263.

Blair, D., Agatsuma, T., Wang, W., 2007. Chapter 3. Paragonimiasis. Fish- and Plant-Borne Parasites, in: Murrell, K.D., Fried, B. (Eds), World Class Parasites. Springer, New York, Vol.11, pp. 117-150.

Boguikouma, J.B., Moussavou-Kombila, J.B., Ondo-Ndong, F., M'vou-Yaloula, R., Mabicka, B., Kombila, M., 1997. Un cas gabonais de paragonimose pulmonaire. Medecine Afrique Noire 44, 431-432.

Bowles, J., Blair, D., McManus, D.P., 1995. A molecular phylogeny of the human schistosomes. Mol. Phylogenet. Evol. 4, 103-109.

Cabaret, J., Bayssade-Dufour, C., Tami, G., Albaret, J.L., 1999. Identification of African paragonimidae by multivariate analysis of the eggs. Acta Trop. 72, 79-89.

Gobert, G.N., Chai, M., Duke, M., McManus, D.P., 2005. Copro-PCR based detection of Schistosoma eggs using mitochondrial DNA markers. Mol. Cell. Probes 19, 250-254.

Ikeda, T., Oikawa, Y., Nishiymaya, T., 1996. Enzyme-linked immunosorbent assay using cysteine proteinase antigens for immunodiagnosis of human paragonimiasis. Am. J. Trop. Med. Hyg. 55, 435-437.

Intapan, P.M., Wongkham, C., Imtawil, K.J., Pumidonming, W., Prasongdee, T.K., Miwa, M., Maleewong, W., 2005. Detection of Paragonimus heterotremus eggs in experimentally infected cats by a polymerase chain reaction-based method. J. Parasitol. 91, 195-198.

Ito, A., Plancarte, A., Ma, L., Kong, Y., Flisser, A., Cho, S.Y., Liu, Y.H., Kamhawi, S., Lightowlers, M.W., Schantz, P.M., 1998. Novel antigens for neurocysticercosis: simple 
method for preparation and evaluation for serodiagnosis. Am. J. Trop. Med. Hyg. 59, 291294.

Keiser, J., Utzinger, J., 2005. Emerging food borne trematodiases. Emerg. Infect. Dis. 11, 15071514.

Kimura, M., 1980. A simple method for estimating evolutionary rate of base substitutions through comparative studies of nucleotide sequences. J. Mol. Evol. 16, 111-120.

Kong, Y., Ito, A., Yang, H.J., Chung, Y.B., Kasuya, S., Kobayashi, M., Liu, Y.H., Cho, S.Y., 1998. Immunoglobulin G (IgG) subclass and IgE responses in human paragonimiases caused by three different species. Clin. Diagn. Lab. Immunol. 5, 474-478.

Kumar, S., Tamura, K., Nei, M., 2004. MEGA3: Integrated software for Molecular Evolutionary Genetics Analysis and sequence alignment. Brief Bioinformatic 5, 150-163.

Mathis, A., Deplazes P., 2006. Copro-DNA tests for diagnosis of animal taeniid cestodes. Parasitol. Int. 55, S87-S90.

Moyou-Somo, R., Tagni-Zukam, D., 2003. Paragonimiasis in Cameroon: clinicoradiologic features and treatment outcome. Medecine Tropicale 63, 163-167.

Moyou-Somo, R., Kefie-Array, C., Dreyfuss, G., Dumas, M., 2003. An epidemiological study of pleuropulmonary paragonimiasis among pupils in the peri-urban zone of Kumba town, Meme division, Cameroon. Biomedical Central Public Health. 3, 40.

Okamoto, M., Bessho, Y., Kamiya, M., Kurosawa, T., Horii, T., 1995. Phylogenetic relationships within Taenia taeniaeformis variants and other taeniid cestodes inferred from the nucleotide sequences of the cytochrome $c$ oxidase subunit I gene. Parasitol. Res. 81, 451-458.

Ollivier, G., Boussinesq, M., Albaret, J.L., Cumberlidge, N., Farhati, K., Chippaux, J.P., Bayssade-Dufour C., 1995. Epidemiological study of Paragonimus sp. in South Cameroon. Bull. Soc. Pathol. Exot. 88, 164-169. 
Ripert, C., Couprie, B., Moyou, R., Gaillard, F., Appriou, M., Tribouley-Duret, J., 1992. Therapeutic effect of triclabendazole in patients with paragonimiasis in Cameroon: a pilot study. Trans. R. Soc. Trop. Med. Hyg. 86, 417.

Ritchie, L. S., 1948. An ether sedimentation technique for routine stool examination. Bull. U.S. Army Med. Dept. 8, 326.

Saitou, N., Nei, M., 1987. The neighbor-joining method: a new method for reconstruction phylogenetic trees. Mol. Biol. Evol. 4, 406-425.

Thompson, J. D., Higgins, D.G., Gibson, T.J., 1994. CLUSTAL W: improving the sensitivity of progressive multiple sequence alignment through sequence weighting, position-specific gap penalties and weight matrix choice. Nucl. Acids Res. 22, 4673-4680.

Toscano, C., Yu, S.H., Nunn, P., Mott, K.E., 1995. Paragonimiasis and tuberculosis, diagnosis confusion: a review of the literature. Trop. Dis. Bull. 92, R1-R26.

Voelker, J., Sachs, R., 1977. On the distribution of lung flukes, Paragonimus africanus and $P$. uterobilateralis in the South West province of Cameroon and in Eastern Nigeria as determined by examination of the intermediate crab hosts for infection with metacercariae. Tropenmed Parasitol. 28, 120-133.

WHO, 1995. Control of food-borne trematode infections. Report of a WHO Study Group. Geneva: World Health Organization, Technical Report Series, No. 849.

WHO, 2002. Global tuberculosis control: surveillance, planning and financing. Geneva: World Health Organization, WHO/CDS/TB/2002. 295.

Xiao, N., Mamuti, W., Yamasaki, H., Sako, Y., Nakao, M., Nakaya, K., Gottstein, B., Schantz, P.M., Lightowlers, M.W., Craig, P.S., Ito, A., 2003. Evaluation of use of recombinant Em18 and affinity-purified Em18 for serological differentiation of alveolar echinococcosis from cystic echinococcosis and other parasitic infections. J. Clin. Microbiol. 41, 3351-3353. 
Yamasaki, H., Allan, J.C., Sato, M.O., Nakao, M., Sako, Y., Nakaya, K., Qiu, D., Mamuti, W., Craig, P.S., Ito, A., 2004. DNA differential diagnosis of taeniasis and cysticercosis by multiplex PCR. J. Clin. Microbiol. 42, 548-553.

Yokogawa, M., 1965. Paragonimus and paragonimiasis. Adv. Parasitol. 3, 99-158. 


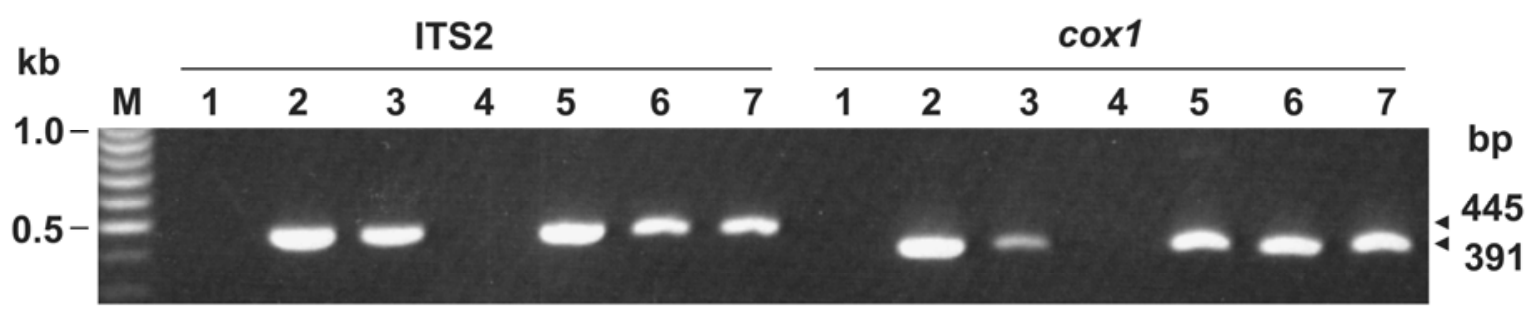

Figure 1. PCR-amplification of the ITS2 region (445 bp) and partial cox1 gene (391 bp) from Paragonimus adult worms and from human faecal materials from Cameroon. M, 100-bp DNA ladder marker; lane 1, negative control without template DNA; lane 2, DNA from adult $P$. africanus from an experimentally infected cat; lanes 3-7 (E20, ET56, T92, T86, T76), coproDNA from sputum egg-positive patients (Table 1). An additional 18 samples from sputum eggnegative individuals, including 2 sero-positive and 16 sero-negative individuals, were PCRnegative (not shown). 


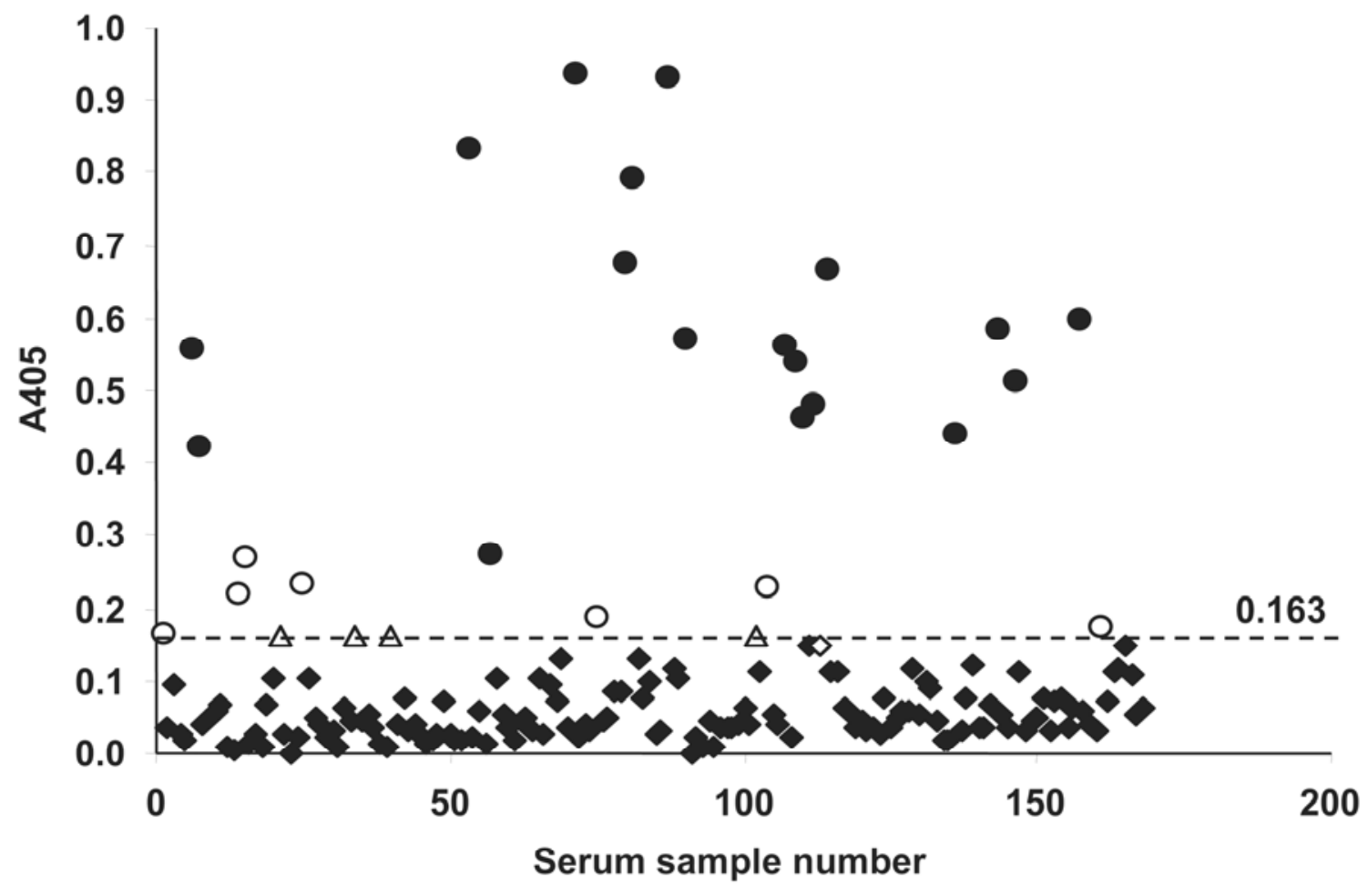

Figure 2. ELISA using P. africanus antigens. The broken line denotes the cut-off value. • ELISA positive showing strong positive reactions with the major bands of 33 and $35 \mathrm{kDas}$ in immunoblot; ○, ELISA positive showing weak positive reactions with 16-18 $\mathrm{kDa}$ or $27 \mathrm{kDa}$ bands in immunoblot; $\square$, ELISA negative but weak positive reactions in immunoblot (Table 1, patient 31); $\mathbf{m}$ ELISA and immunoblot negative; $\Delta$, samples on the cut-off line for ELISA. 


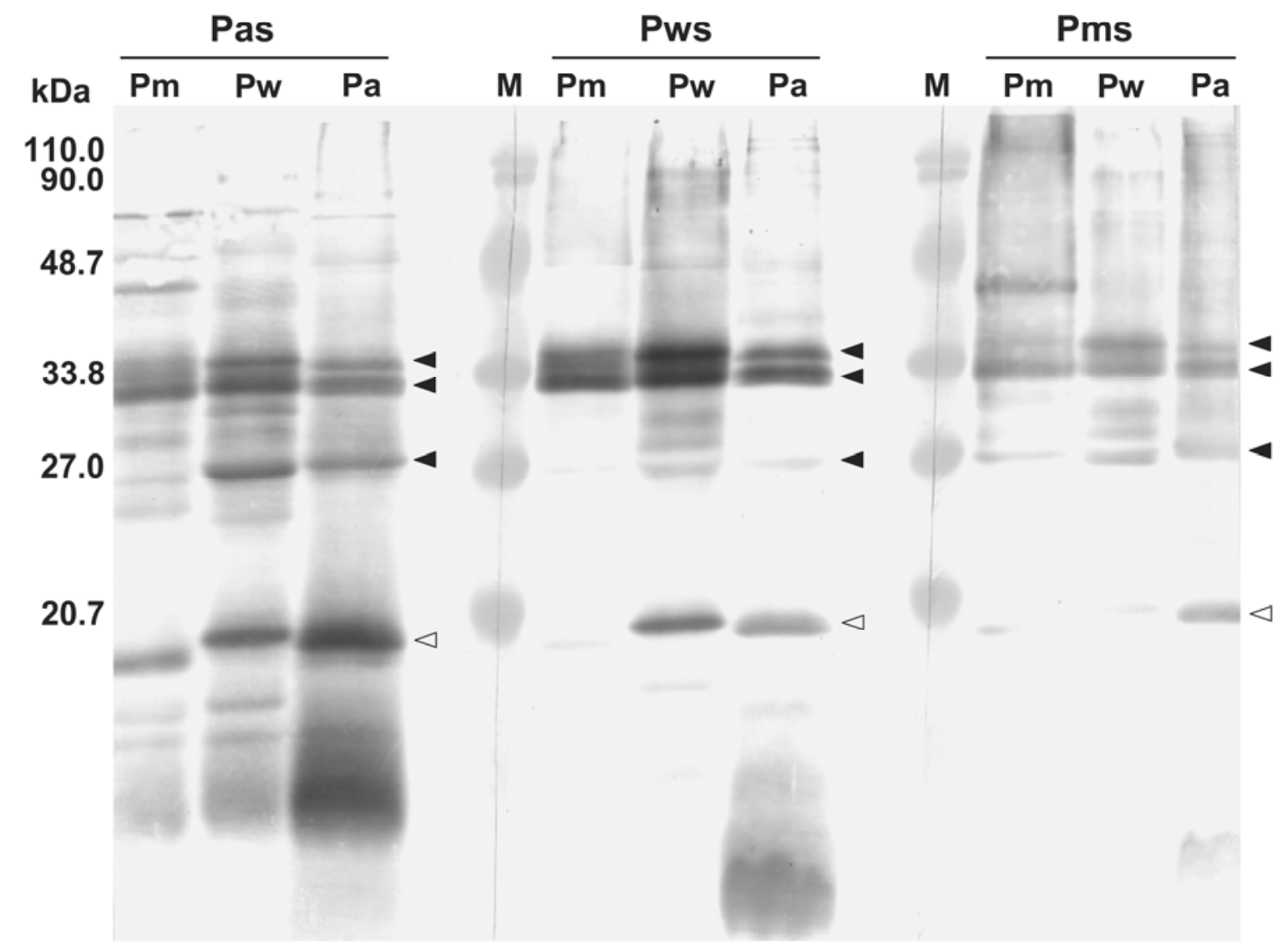

Figure 3. Immunoblot results using antigens from three Paragonimus species and serum sample from paragonimiasis patients. Pas, serum sample from a Cameroonian patient infected with $P$. africanus; Pws, serum sample from a P. westermani-infected patient from Japan; Pms, serum sample from a $P$. miyazakii-infected patient from Japan; Pm, P. miyazakii antigens; Pw, $P$. westermani antigens; Pa, P. africanus antigens. Closed arrow heads indicate 35, 33, and $27 \mathrm{kDa}$ specific bands for paragonimiasis, whereas an open arrow head denotes low-molecular specific bands (16-18 kDa). The sizes of molecular marker $(\mathrm{M})$ are shown on the left side. 


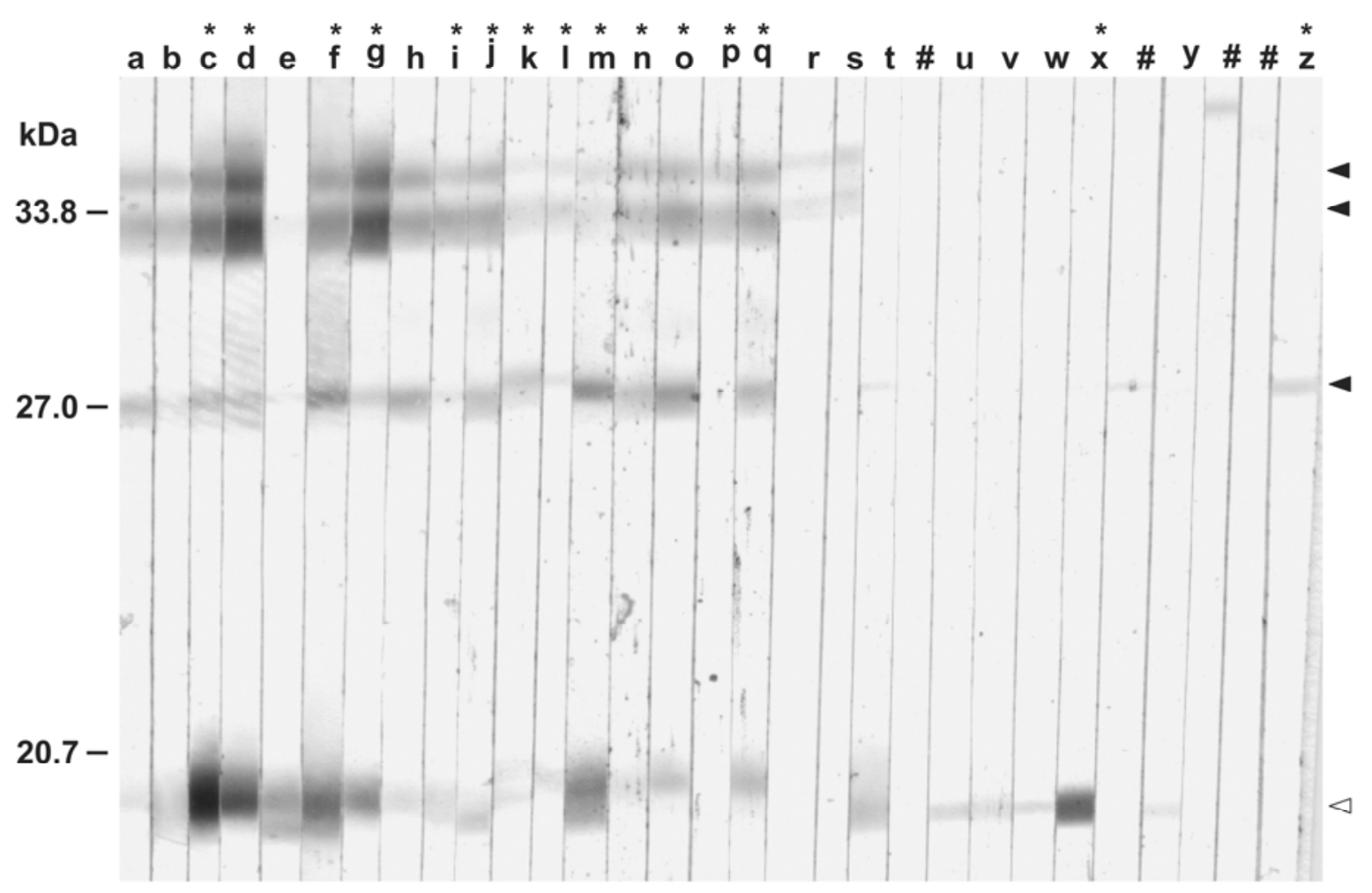

Supplementary figure. Immunoblot results using P. africanus antigens. ELISA-positive samples (lanes a to z) and additional 4 samples (\#) that were on the cut-off line for ELISA (see figure. 2, symbol $\Delta$ ) were used. Samples of lanes a to $r$ showed strong reactions in ELISA, whereas samples of lanes $\mathrm{s}$ to $\mathrm{z}$ were weak. Asterisks indicate egg-positive individuals. Closed and open arrow heads denote specific bands for paragonimiasis. The positions of molecular marker are shown on the left side. 
Table 1. Summary of clinical, parasitological, serological and molecular data of 26 persons diagnosed as suffering from paragonimiasis

\begin{tabular}{|c|c|c|c|c|c|c|c|c|c|c|}
\hline \multirow[t]{2}{*}{$\begin{array}{l}\text { Patients } \\
\text { Code }\end{array}$} & \multirow[t]{2}{*}{$\begin{array}{l}\text { Age/ } \\
\text { Sex }\end{array}$} & \multirow[t]{2}{*}{$\begin{array}{l}\text { Eggs in } \\
\text { sputum }\end{array}$} & \multicolumn{2}{|c|}{ Serology } & \multirow[t]{2}{*}{$\begin{array}{l}\text { Copro- } \\
\text { DNA }\end{array}$} & \multicolumn{5}{|c|}{$\begin{array}{c}\text { Clinical Signs and Symptoms/History of } \\
\text { eating crabs }\end{array}$} \\
\hline & & & $\begin{array}{l}\text { ELISA } \\
\end{array}$ & IB & & Cough & Headache & Epilepsy & $\begin{array}{l}\text { Chest } \\
\text { pain }\end{array}$ & $\begin{array}{l}\text { Crabs } \\
\text { eaten }\end{array}$ \\
\hline B07 & $5 / \mathrm{M}$ & - & + & + & - & $+^{*}$ & + & - & + & + \\
\hline B08 & $6 / \mathrm{F}$ & - & + & + & - & + & + & - & + & + \\
\hline ET56 & $8 / \mathrm{F}$ & + & + & + & - & $+*$ & - & - & - & + \\
\hline $\mathrm{T} 76$ & $8 / \mathrm{F}$ & + & + & + & + & $+*$ & - & - & - & + \\
\hline T85 & $11 / \mathrm{M}$ & - & + & + & ND & + & - & - & + & + \\
\hline T86 & $8 / \mathrm{F}$ & + & + & + & + & $+^{*}$ & + & - & + & + \\
\hline T92 & $12 / \mathrm{M}$ & + & + & + & + & $+^{*}$ & + & - & + & + \\
\hline T95 & 9/F & - & + & + & ND & + & - & - & - & + \\
\hline 8 & $14 / \mathrm{F}$ & + & + & + & ND & $+*$ & + & - & + & + \\
\hline 10 & $8 / \mathrm{F}$ & + & + & + & ND & + & + & - & + & + \\
\hline 12 & $24 / F$ & + & + & + & ND & $+*$ & + & - & - & + \\
\hline 14 & $23 / \mathrm{F}$ & + & + & + & ND & + & + & - & + & + \\
\hline 16 & $13 / \mathrm{M}$ & + & + & + & ND & $+*$ & - & - & + & + \\
\hline 39 & $5 / \mathrm{F}$ & + & + & + & ND & + & + & - & + & + \\
\hline 46 & $6 / \mathrm{F}$ & + & + & + & ND & + & - & - & + & + \\
\hline 49 & 7/M & + & + & + & ND & + & - & - & + & + \\
\hline E35 & $10 / \mathrm{M}$ & - & + & + & ND & + & + & - & - & + \\
\hline ET60 & $10 / \mathrm{M}$ & - & + & + & ND & + & + & - & - & + \\
\hline ET62 & $11 / \mathrm{F}$ & - & + & + & ND & + & + & - & - & + \\
\hline ET73 & $12 / \mathrm{F}$ & - & + & + & ND & + & + & - & - & + \\
\hline 72 & 9/M & - & + & + & ND & + & + & + & + & + \\
\hline 31 & $8 / \mathrm{F}$ & + & - & + & ND & + & + & - & - & + \\
\hline 65 & $12 / \mathrm{M}$ & + & + & + & ND & + & - & - & + & + \\
\hline 66 & $10 / \mathrm{M}$ & - & + & + & ND & + & + & - & + & + \\
\hline 61 & $12 / \mathrm{F}$ & + & + & + & ND & + & + & - & + & + \\
\hline E20 & $18 / \mathrm{M}$ & + & + & + & + & $+*$ & + & - & + & + \\
\hline
\end{tabular}

Note. IB, immunoblot; +, positive; -, negative; +*, cough with haemoptysis; ND, not done. The negative results of copro-PCR was obtained from a further 16 egg-negative individuals. 